\title{
Non coding RNA
}

INSERM

\section{Source}

INSERM. (1999). Orphanet: an online rare disease and orphan drug data base. non coding RNA. ORPHA:410299

RNA transcript not translated into protein. 